\title{
Steviol Glycosides Modulate Glucose Transport in Different Cell Types
}

\author{
Benedetta Rizzo, ${ }^{1}$ Laura Zambonin, ${ }^{2}$ Cristina Angeloni, ${ }^{1}$ Emanuela Leoncini, ${ }^{1}$ \\ Francesco Vieceli Dalla Sega, ${ }^{2}$ Cecilia Prata, ${ }^{2}$ Diana Fiorentini, ${ }^{2}$ and Silvana Hrelia ${ }^{1}$ \\ ${ }^{1}$ Department for Life Quality Studies, Alma Mater Studiorum, University of Bologna, Corso Augusto 237, 47921 Rimini, Italy \\ ${ }^{2}$ Department of Pharmacy and Biotechnology, Alma Mater Studiorum, University of Bologna, Via Irnerio 48, 40126 Bologna, Italy
}

Correspondence should be addressed to Laura Zambonin; laura.zambonin@unibo.it

Received 25 July 2013; Revised 27 September 2013; Accepted 30 September 2013

Academic Editor: Tullia Maraldi

Copyright (C) 2013 Benedetta Rizzo et al. This is an open access article distributed under the Creative Commons Attribution License, which permits unrestricted use, distribution, and reproduction in any medium, provided the original work is properly cited.

Extracts from Stevia rebaudiana Bertoni, a plant native to Central and South America, have been used as a sweetener since ancient times. Currently, Stevia extracts are largely used as a noncaloric high-potency biosweetener alternative to sugar, due to the growing incidence of type 2 diabetes mellitus, obesity, and metabolic disorders worldwide. Despite the large number of studies on Stevia and steviol glycosides in vivo, little is reported concerning the cellular and molecular mechanisms underpinning the beneficial effects on human health. The effect of four commercial Stevia extracts on glucose transport activity was evaluated in HL-60 human leukaemia and in SH-SY5Y human neuroblastoma cells. The extracts were able to enhance glucose uptake in both cellular lines, as efficiently as insulin. Our data suggest that steviol glycosides could act by modulating GLUT translocation through the PI3K/Akt pathway since treatments with both insulin and Stevia extracts increased the phosphorylation of PI3K and Akt. Furthermore, Stevia extracts were able to revert the effect of the reduction of glucose uptake caused by methylglyoxal, an inhibitor of the insulin receptor/PI3K/Akt pathway. These results corroborate the hypothesis that Stevia extracts could mimic insulin effects modulating PI3K/Akt pathway.

\section{Introduction}

Stevia rebaudiana Bertoni is a weak perennial shrub belonging to Asteraceae (Compositae) family, native to subtropical regions of Brazil and Paraguay. Its leaves have been used as a sweetener since ancient times and for many other medicinal purposes in Latin America and the Orient for centuries $[1,2]$. The "sweet herb" has gained increasing interest from nutritional researchers and commercial area in the last years, due to the growing need to find new natural calorie-free sweeteners alternative to sugar. Indeed, in both industrialized and developing countries, the incidence of type 2 diabetes mellitus and obesity is sharply increasing as a result of dietary behaviours, reduced physical activities, and ageing. These metabolic disorders have become major public health problems worldwide $[3,4]$.

Glycemic control is fundamental to the management of diabetes since it is associated with significantly decreased rates of retinopathy, nephropathy, neuropathy, and cardiovascular disease, the most common cause of death in diabetic patients. The effort to achieve near-normoglycemia through the key strategy of glycemic control includes recommendations for prevention and control of diabetes, for example, monitoring carbohydrate intake and limiting the consumption of sugar-sweetened beverages [5].

Stevia leaves and extracts are natural noncaloric sweeteners that can substitute sucrose. The main sweet components in leaves, approximately 200-400 times sweeter than sucrose as shown by organoleptic tests $[1,6]$, are stevioside and rebaudioside A, steviol glycosides differing only by one glucose moiety. Stevioside is formed by 3 molecules of glucose and one molecule of the aglycone steviol, a diterpenic carboxylic alcohol; rebaudioside A holds one additional glucose molecule [7] (Figure 1).

Steviol glycosides have been recently authorised as commercial sweeteners. US Food and Drug Administration 


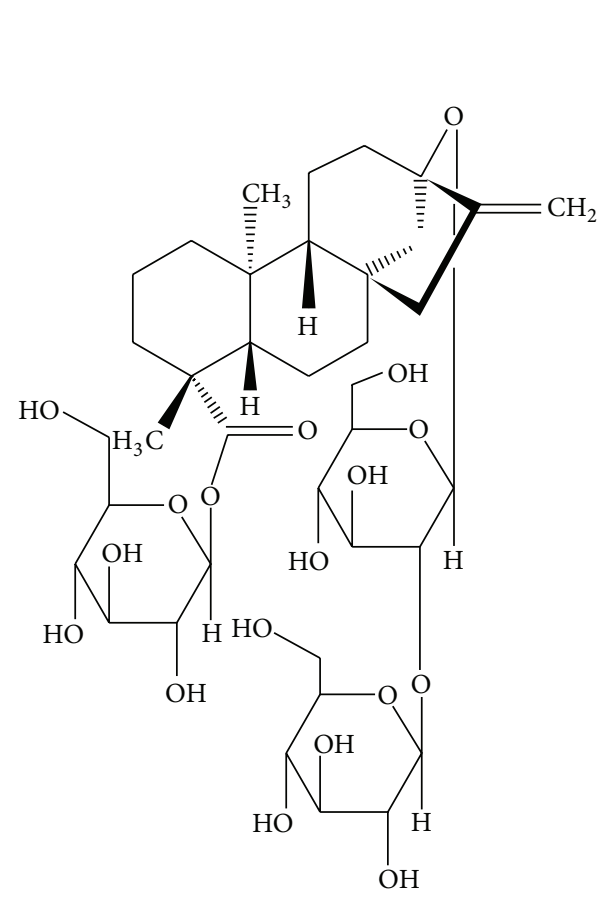

(a)

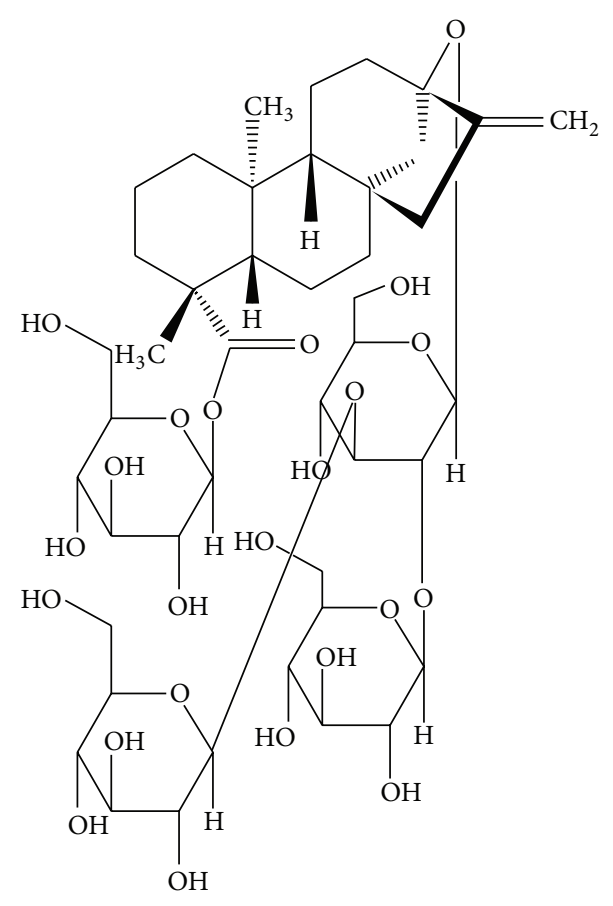

(b)

FIGURE 1: Chemical structure of stevioside (a) and rebaudioside A (b).

(FDA) has allowed the use of Stevia extracts containing not less than 95\% total steviol glycosides. Recently, the European Food Safety Authority (EFSA) approved the use of steviol glycosides as food additive $[8,9]$. Considering the available toxicity data (in vitro and in vivo animal studies and some human tolerance studies), steviol glycosides are considered not carcinogenic, genotoxic, or associated with any reproductive/developmental toxicity. Joint Expert Committee on Food Additives (JECFA) established an accepted daily intake (ADI) for steviol glycosides (expressed as steviol equivalents) of $4 \mathrm{mg} / \mathrm{kg}$ bw/day [10, 11].

Besides sweetness, steviol glycosides, in particular stevioside, have been shown to possess beneficial effects on human health $[7,12,13]$. Briefly, pharmacological activities and therapeutical benefits include antitumour and anticancer, antiinflammatory, antihyperglycemic, antihypertensive, antidiarrheal, immunomodulatory, diuretic, and enzyme inhibitory actions. Stevia has also been used to help control weight in obese subjects [14]; moreover, antioxidant properties have been described $[15,16]$. Stevioside, rebaudioside A, and their metabolite steviol have been mostly investigated in in vivo animal studies and, at a lesser extent, in humans. Results suggest that stevioside and related compounds affect plasma glucose modulating insulin secretion and sensitivity, which increase glucose removal from the plasma $[17,18]$. In addition, it seems likely that stevioside inhibits gluconeogenesis in the liver of diabetic rats $[19,20]$. These antihyperglycemic, insulinotropic, and glucagonostatic effects, especially for rebaudioside $\mathrm{A}$, are largely plasma glucose level dependent, requiring high glucose levels $[21,22]$. Despite the large number of studies on Stevia and steviol glycosides, very little is reported concerning the cellular and molecular mechanisms underpinning these effects.

In the present study, we examined the role of steviol glycosides on cellular glucose transport in cultured cells. Glucose is a polar molecule and requires specific carrier proteins, located in the plasma membrane, to cross the lipid bilayer and enter the cell. Glucose is transported into the cells through two different types of membrane associated carrier proteins, the $\mathrm{Na}^{+}$-coupled glucose transporters (SGLT) and the facilitative glucose transporters (GLUT). The human GLUT family is integral membrane proteins widely distributed in probably all mammalian cells that regulate the movement of glucose between extracellular and intracellular compartments maintaining a constant supply of glucose available for metabolism [23]. To date, GLUT family is constituted by 14 distinct isoforms, differently distributed in human tissues $[23,24]$. GLUT1 is considered responsible for the basal uptake in many cell types, representing the most ubiquitously expressed isoform; GLUT4 is responsible for insulin-stimulated glucose uptake in peripheral tissues, but its expression has also been reported in the brain [25, 26], where glucose is an essential substrate for cerebral oxidative metabolism. It has recently been reported that in a human neuronal cell line, SH-SY5Y, GLUT1 translocation in response to insulin-like growth factor (IGF-I) occurs [27] and, for the first time in a neuronal cell system, also GLUT4 is translocated to the plasma membrane in response to insulin [28]. We have been studying for a long time the glucose transport activity in many leukaemia cell lines expressing mainly GLUT1, demonstrating that, also in these cell types, GLUT1 is recruited on the plasma membrane from 
intracellular compartments in response to different stimuli, greatly enhancing the rate of glucose uptake $[29,30]$. Moreover, it is well known that impaired GLUT4 translocation is causally linked to insulin resistance and consequently to noninsulin-dependent diabetes mellitus $[31,32]$.

Starting from this knowledge and this background, we chose the neuroblastoma SH-SY5Y and the promyelocytic leukaemia line HL-60, both expressing insulin and insulinlike growth factor-1 (IGF-I) receptors $[28,33]$ to test some commercial Stevia extracts, in order to evaluate a possible effect of these compounds on glucose transport and to clarify the molecular mechanism of action.

\section{Materials and Methods}

2.1. Chemicals and Reagents. Dulbecco's modified Eagle's medium (DMEM), foetal calf serum (FCS), penicillin/streptomycin, 3-(4, 5-dimethylthiazol-2-yl)-2, 5-diphenyltetrazolium bromide (MTT), staurosporine, $2^{\prime}, 7^{\prime}$-dichlorodihydrofluorescein diacetate $\left(\mathrm{H}_{2} \mathrm{DCFDA}\right.$, dichlorofluorescin diacetate), 2-deoxy-glucose (DOG), phloretin, Cellytic M, mammalian protease inhibitor mixture, primary antibody to $\beta$-actin, methylglyoxal (MG), hydrogen peroxide, bovine serum albumin (BSA), rebaudioside A standard (StReb), stevioside standard (StStev), and all other chemicals of the highest analytical grade were purchased from SigmaAldrich. Roswell Park Memorial Institute (RPMI) 1640 medium (with Hepes, with L-glutamine) was purchased from PAA. 2-Deoxy-D-[2, 3]-glucose and Ultima Gold MV scintillation cocktail were from PerkinElmer. PhosSTOP, a phosphatase inhibitor cocktail, was obtained from Roche Diagnostic. Nitrocellulose membranes and Amersham ECL Advance Western Blotting Detection Reagents were from GE-Healthcare. Primary antibodies against phospho-Akt (Ser473) (no. 4058), total Akt (no. 9272), and horseradish peroxidase-conjugated secondary antibodies anti-rabbit (no. 7074) and anti-mouse (no. 7076) were purchased from Cell Signaling Technologies. Anti-GLUT1 (sc-1603), anti-GLUT4 (sc-1606) antibodies, and anti-goat IgG conjugated to horseradish peroxidase (sc-2020) were obtained from Santa Cruz Biotechnology. Primary antibody anti-phospho-PI3 Kinase p85 pTyr458/p55 pTyr199 (no. PA5-17387) was from Thermo Scientific. Anti-PI3 Kinase (no. 06-195) antibody was purchased from Millipore. PageRuler Prestained protein ladder was from Fermentas-Thermo Fisher Scientific.

Extracts from Stevia rebaudiana Bertoni were kindly supplied by Eridania Sadam SpA.

According to FDA and EFSA [8-11], total content of steviol glycosides in commercial Stevia extracts has to be at least $95 \%(\mathrm{w} / \mathrm{w})$, and rebaudioside A plus stevioside must be at least $75 \%$. The four extracts tested differ by the relative content of rebaudioside $\mathrm{A}$ and stevioside. In particular, according to the certificates of analysis of each sweetener, Reb A (R97) contains 97-98\% rebaudioside A, Stevia RA60 (R60) contains about $60 \%$ rebaudioside $A$ and about $20 \%$ stevioside; Steviol Glycosides SG95 (SG) contains 50\% rebaudioside A and at least $25 \%$ stevioside; Truvia (TRU) contains a mixture of steviol glycosides not analytically quantified.
2.2. Cell Culture. SH-SY5Y, human neuroblastoma cells, were grown at $37^{\circ} \mathrm{C}$ in a humidified incubator with $5 \% \mathrm{CO}_{2}$ in Dulbecco's modified Eagle's medium (DMEM) supplemented with $10 \%(\mathrm{v} / \mathrm{v})$ foetal bovine serum (FBS), $2 \mathrm{mM}$ glutamine, $50 \mathrm{U} / \mathrm{mL}$ penicillin, and $50 \mu \mathrm{g} / \mathrm{mL}$ streptomycin, as reported in [34]. HL-60, acute myeloid leukaemia cells, were cultured in RPMI-1640 medium supplemented with $10 \%$ FBS, $2 \mathrm{mM}$ glutamine, $100 \mathrm{U} / \mathrm{mL}$ penicillin, and $100 \mu \mathrm{g} / \mathrm{mL}$ streptomycin, at $37^{\circ} \mathrm{C}$ in a humidified atmosphere maintained at $5 \% \mathrm{CO}_{2}$.

2.3. Cell Viability. Cells were treated with different concentrations of steviol glycosides $(0.5$ to $5 \mathrm{mg} / \mathrm{mL}$ ) or $1 \mathrm{mM}$ (corresponding to $1 \mathrm{mg} / \mathrm{mL}$ ) StReb or $1 \mathrm{mM}$ (corresponding to $0.8 \mathrm{mg} / \mathrm{mL}$ ) StStev for $24 \mathrm{~h}$. Cell viability was evaluated by the MTT assay as reported in [35]. SH-SY5Y and HL-60 cells were incubated with $0.5 \mathrm{mg} / \mathrm{mL}$ MTT for $4 \mathrm{~h}$ at $37^{\circ} \mathrm{C}$ in multiwell plates. At the end of the incubation, blue-violet formazan salt crystals were formed and dissolved by adding the solubilisation solution ( $10 \%$ SDS, $0.01 \mathrm{M} \mathrm{HCl})$; then the plates were incubated overnight in humidified atmosphere $\left(37^{\circ} \mathrm{C}, 5 \% \mathrm{CO}_{2}\right)$ to ensure complete lysis. The absorbance at $570 \mathrm{~nm}$ was measured using a multiwell plate reader (Wallac Victor $^{2}$, PerkinElmer).

2.4. Lactate Dehydrogenase Assay. SH-SY5Y and HL-60 cells were incubated with $1 \mathrm{mg} / \mathrm{mL}$ of each Stevia extract for 24 h. Lactate dehydrogenase (LDH) release from cells was monitored by collecting aliquots of medium. LDH activity was assayed by a spectrophotometric method based on the reduction of pyruvate to lactic acid coupled to NADH oxidation. The decrease in absorbance at $340 \mathrm{~nm}$ was monitored at $37^{\circ} \mathrm{C} .100 \mu \mathrm{M} \mathrm{H}_{2} \mathrm{O}_{2}$ for 30 minutes was used as a positive control.

2.5. Assay for Caspase 3 Activity. Caspase 3 activity in the cell lysates was measured using a colorimetric assay kit by following the instructions from the manufacturer (Sigma), as described in [36]. Cells were incubated with or without steviol glycosides $(1 \mathrm{mg} / \mathrm{mL})$ for 1,6 , or $24 \mathrm{~h}$. After $24 \mathrm{~h}$, cells were collected and lysed using the lysis buffer provided in the kit $(250 \mathrm{mM}$ HEPES, pH 7.4 containing $25 \mathrm{mM}$ CHAPS, and $25 \mathrm{mM}$ DTT). The assay was based on the hydrolysis of the peptide substrate acetyl-Asp-Glu-ValAsp-aminomethylcoumarin (Ac-DEVD-AMC) by caspase 3, resulting in the release of free AMC moiety. The fluorescence of AMC was read using a multiwell plate reader (Wallac Victor $^{2}$, PerkinElmer); excitation and emission wavelengths were $360 \mathrm{~nm}$ and $460 \mathrm{~nm}$, respectively.

The concentration of the AMC released was calculated using an AMC standard curve. Caspase 3 activity was expressed in nmole of AMC released per min per $\mathrm{mL}$ of cell lysate and normalised for total protein content in the lysate. Results are reported as percentage with respect to the control. Staurosporine $(1 \mu \mathrm{g} / \mathrm{mL})$ was used as an apoptosis inducer (positive control). 
2.6. Measurement of Intracellular Reactive Oxygen Species (ROS) Levels. ROS intracellular level was evaluated by using the fluorescent probe $2^{\prime}, 7^{\prime}$-dichlorodihydrofluorescein diacetate $\left(\mathrm{H}_{2} \mathrm{DCFDA}\right)$. SH-SY5Y and HL-60 cells were incubated with $5 \mathrm{mg} / \mathrm{mL}$ of each Stevia extract for $1 \mathrm{~h}$ and then subjected or not to oxidative stress generated by $100 \mu \mathrm{M} \mathrm{H}_{2} \mathrm{O}_{2}$ for 30 minutes. Successively, cells were washed twice in PBS and incubated with $5 \mu \mathrm{M} \mathrm{H} \mathrm{H}_{2}$ DCFDA for $20 \mathrm{~min}$ at $37^{\circ} \mathrm{C}$. $\mathrm{H}_{2}$ DCFDA is a small nonpolar, nonfluorescent molecule that diffuses into the cells, where it is enzymatically deacetylated by intracellular esterases to a polar nonfluorescent compound, that is oxidised to the highly green fluorescent $2^{\prime}, 7^{\prime}$ dichlorofluorescein (DCF). The fluorescence of oxidized probe was measured using a multiwell plate reader (Wallac Victor $^{2}$, PerkinElmer). Excitation wavelength was $485 \mathrm{~nm}$ and emission wavelength was $535 \mathrm{~nm}$. Fluorescence values were reported as the percentage of intracellular ROS with respect to control.

2.7. Glucose Transport Assay. Glucose transport assay was performed as described in [37, 38]. Cells were incubated or not with different compounds $(1 \mathrm{mg} / \mathrm{mL})$ for $1 \mathrm{~h}$; then they were washed twice in PBS and treated for $10 \mathrm{~min}$ (SH-SY5Y) or $2 \mathrm{~min}$ (HL-60) at $37^{\circ} \mathrm{C}$ with a mixture of 2 -deoxy-D$[2,3]$ glucose $(0.8 \mu \mathrm{Ci}$ /assay $)$ and $1.0 \mathrm{mM}$ unlabeled glucose analogue, under conditions where the uptake was linear at least for $20 \mathrm{~min}$. The transport was stopped by adding phloretin (final concentration $0.3 \mathrm{mM}$ ), a potent inhibitor of glucose transport activity. Radioactivity was measured by liquid scintillation counting (Tri-Carb liquid scintillation analyser, PerkinElmer).

2.8. Immunoblotting Analysis. After treatments, cells were washed with ice-cold PBS and lysed on ice using CelLytic M containing mammalian protease and phosphatase inhibitor mixture. The resulting lysed cells were left on ice to solubilize for $45 \mathrm{~min}$. The lysates were centrifuged at $5000 \mathrm{~g}$ for $5 \mathrm{~min}$ at $4^{\circ} \mathrm{C}$ to remove unbroken cell debris and nuclei. Cell lysate protein concentration was determined by the Bio-Rad Bradford protein assay (Bio-Rad Laboratories). Samples were kept at $95^{\circ} \mathrm{C}$ for $5 \mathrm{~min}$ prior to separation on $10 \%$ SDSPAGE Mini-Protean TGX precast gels using a Mini-Protean apparatus (Bio-Rad Laboratories). Proteins (15 $\mu \mathrm{g} / \mathrm{lane}$ ) were electrophoretically transferred to nitrocellulose membrane (Hybond-C; GE Healthcare) in Tris-glycine buffer at $110 \mathrm{~V}$ for $90 \mathrm{~min}$. Membranes were then incubated in blocking buffer containing 5\% (w/v) albumin in Tris-buffered saline (TBS)/Tween to avoid nonspecific binding and incubated overnight at $4^{\circ} \mathrm{C}$ with primary antibodies (anti-GLUT1, antiGLUT4, anti-phospho-Akt, anti-total Akt, anti-phospho$\mathrm{PI} 3 \mathrm{~K}$, anti-total-PI3K, or anti- $\beta$-actin as internal normalizer). Nitrocellulose membranes were then washed 3 times with TBS/Tween and incubated with secondary antibodies in TBS/Tween containing 5\% albumin for $60 \mathrm{~min}$ at room temperature and successively washed with TBS/Tween. The results were visualized by chemiluminescence using ECL Advance reagent according to the manufacturer's protocol (GE Healthcare). Images of the blots were obtained using a
CCD imager (ChemiDoc MP System, Bio-Rad). Bands were acquired and analysed by using Image Lab analysis software.

2.9. Statistical Analysis. Results are expressed as means \pm SD. Differences among the means were determined by Bonferroni multiple comparison test following one-way ANOVA and were considered significant at $P<0.05$.

\section{Results and Discussion}

The effect of different commercial extracts from Stevia rebaudiana Bertoni on glucose transport was investigated in both SH-SY5Y neuroblastoma and HL-60 myeloid leukaemia human cells.

Glucose is the primary source of energy used by the brain and it is constantly delivered to individual cells (glial cells and neurons) [39]. In brain, the relationship among glucose metabolism, GLUT isoforms, modulation of glucose uptake, role of insulin, and distribution of insulin receptor (IR) is very complex, being dependent on specific regions of the brain and playing a key role also in cognitive functions. Recent studies report a close correlation between impaired glucose uptake/metabolism and neurodegenerative diseases such as Alzheimer's disease [40-42].

It is also recognised that cancer cells frequently overexpress the GLUT family members, due to the uncontrolled proliferation requiring elevated energy, and they often express GLUT isoforms not present in normal conditions. Moreover, large hypoxic areas into the tumour cause an increase in glucose utilization by cancer cells through glycolysis. The requirement for energy is satisfied by an augmented sugar intake, realised by an increase in GLUT expression and an increment in the translocation of the transporters to the plasma membrane [23]. For these reasons, cancer cells are a useful model system to study the glucose transport activity and its signalling transduction pathway, allowing to clarify the molecular mechanism underlying steviosides biological effects on glucose metabolism.

The first aim of our paper was to evaluate the effect of four different Stevia extracts on cellular viability, assessed by MTT assay. SH-SY5Y and HL-60 cells were treated with different concentrations $(0.5-5 \mathrm{mg} / \mathrm{mL}$, corresponding to $0.5-5 \mathrm{mM}$ for R97, which can be assumed as a pure compound) of Stevia extracts for $24 \mathrm{~h}$. Data reported in Figure 2 show that the extracts did not affect cell viability/proliferation, confirming that they are not cytotoxic within the concentration range tested. Same results were obtained with similar concentrations of StReb or StStev (data not shown).

Cytotoxicity was also evaluated by lactate dehydrogenase (LDH) assay, which indicated that cell membrane integrity was not compromised and excluded cellular necrosis (Figure 3).

In order to evaluate a possible effect on apoptosis, the activity of caspase 3 was measured. Caspases play a central role in mediating various apoptotic responses and are activated in a sequential cascade of cleavages. To detect the enzymatic activity of caspase 3, the fluorogenic substrate AcDEVD-AMC was employed. Treatments of cells with Stevia 


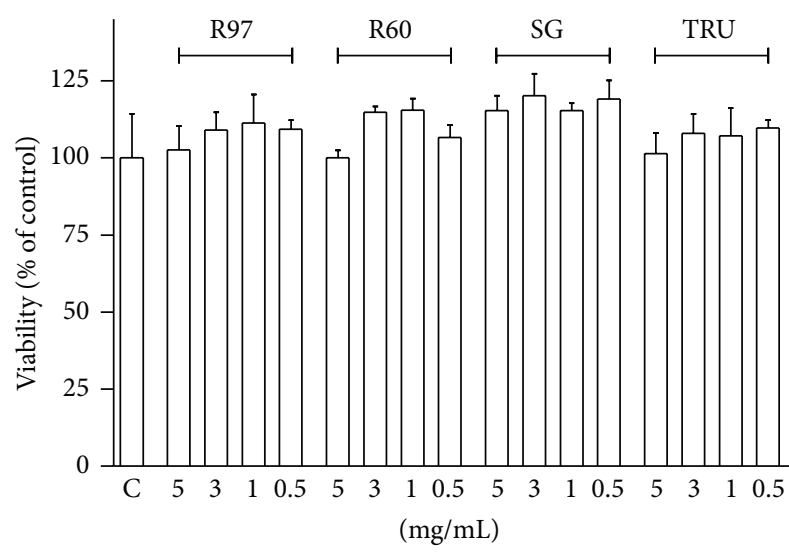

(a)

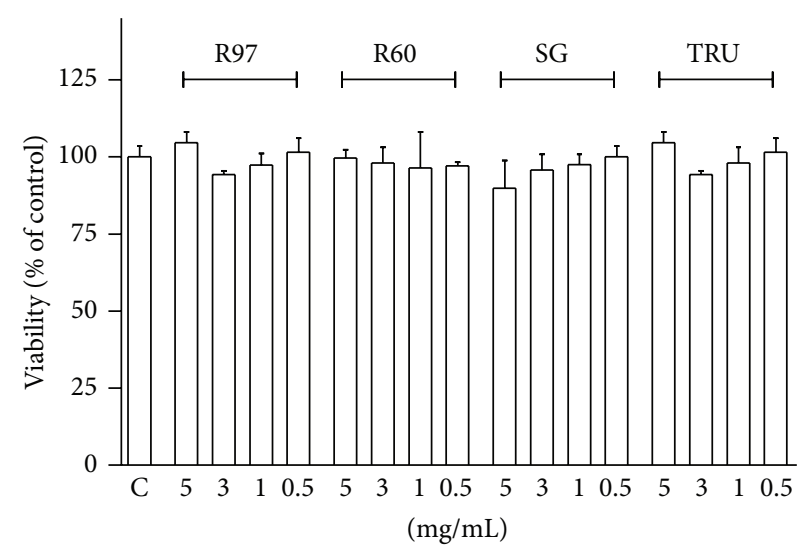

(b)

FIGURE 2: Effect of steviol glycosides on cell viability/proliferation. SH-SY5Y (a) and HL-60 (b) cells were treated for 24 hours with different concentrations of the four compounds $(0.1 \mathrm{mg} / \mathrm{mL}$ to $5 \mathrm{mg} / \mathrm{mL})$. Viability/proliferation was evaluated by MTT assay as described in Section 2 and compared to control $(\mathrm{C})$. Results are expressed as means \pm SD of three independent experiments $(n=8)$. Statistical analysis was performed by Bonferroni multiple comparison test following one-way ANOVA. Significant differences were not revealed.

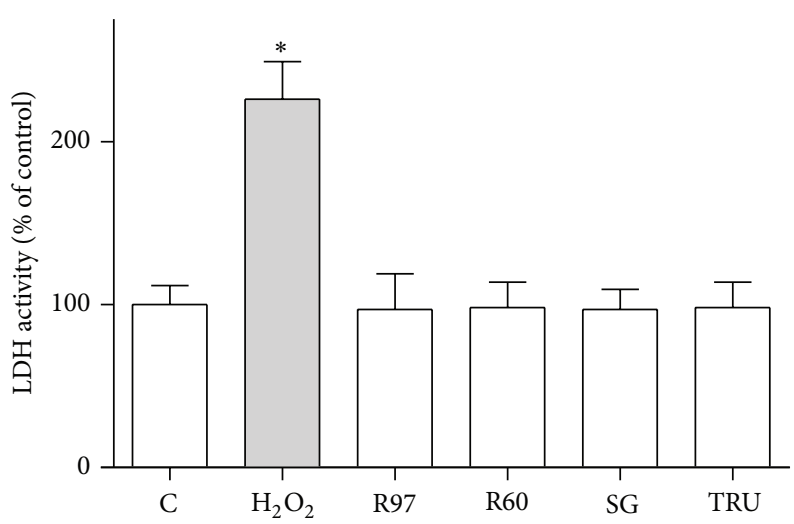

(a)

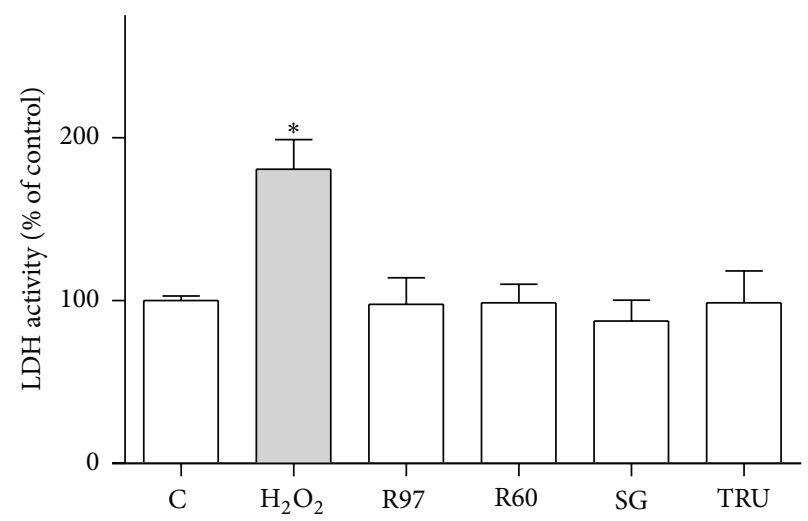

(b)

FIGURE 3: Effect of steviol glycosides treatment on lactate dehydrogenase (LDH) activity. LDH activity was measured by LDH assay as described in Section 2. SH-SY5Y (a) and HL-60 (b) cells were treated with different compounds at $1 \mathrm{mg} / \mathrm{mL}$ final concentration for 24 hours, or cells were treated with $100 \mu \mathrm{M} \mathrm{H}_{2} \mathrm{O}_{2}$ for 30 min as control of LDH activity. Results are expressed as means \pm SD of three independent experiments, each performed in triplicate. Statistical analysis was performed by Bonferroni multiple comparison test following one-way ANOVA. ${ }^{*} P<0.05$, significantly different from control cells.

extracts for 1 hour, 6 hours (data not shown), or for 24 hours (Figure 4) did not influence caspase 3 activity, indicating that the compounds did not induce programmed cell death.

Since antioxidant properties of Stevia extracts have been described $[15,16]$, the antioxidant activity of the commercial extracts was investigated in SH-SY5Y and HL-60 cells. Reactive oxygen species (ROS) levels were measured with the cellpermeant probe $\mathrm{H}_{2}$ DCFDA, commonly used to detect free radical/ROS production in cells, owing to the intracellular conversion to the highly green fluorescent DCF [43]. As shown in Figure 5, the compounds did not exhibit any antioxidant activity, since they were neither able to decrease basal ROS level at the highest concentration used nor to counteract intracellular ROS raise due to exogenous oxidative stress $\left(100 \mu \mathrm{M} \mathrm{H}_{2} \mathrm{O}_{2}\right.$ for $\left.30 \mathrm{~min}\right)$. This lack of antioxidant activity is in contrast with the data reported by other authors
$[15,16]$, probably because the compounds used in the present study are commercial sweeteners containing $95-98 \%$ steviol glycosides with no appraisable amounts of polyphenols, naturally present in Stevia leaves, likely responsible for Stevia antioxidant activity.

Stevia extracts are largely used as a noncaloric highpotency biosweetener substitute for sugar. The effect of four Stevia extracts on glucose transport activity was evaluated in HL-60 human leukaemia cells, expressing principally GLUT1, the basal glucose transporter, and in SH-SY5Y human neuroblastoma cells, expressing also GLUT4, the insulinsensitive one. Figure 6 shows that all the extracts and the two standard compounds were able to enhance glucose uptake at similar extent after 1-hour incubation in both cellular lines.

Since the increase in glucose uptake obtained with standards is consistent with that shown by the whole extracts, we 


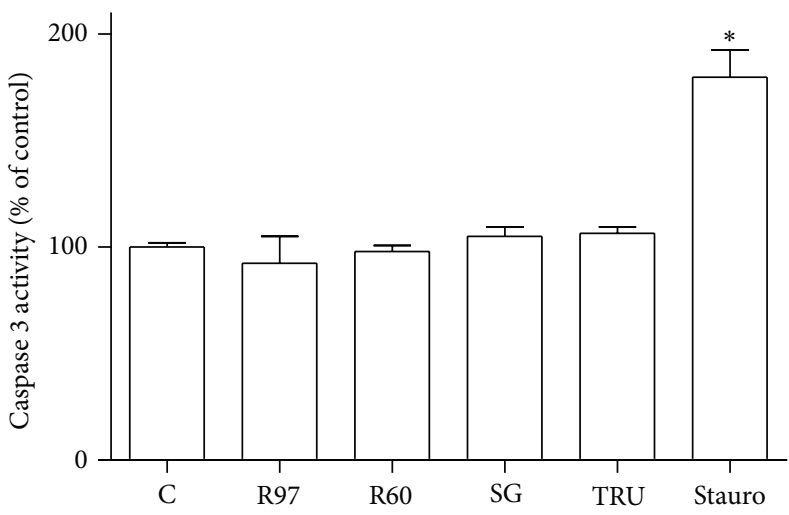

(a)

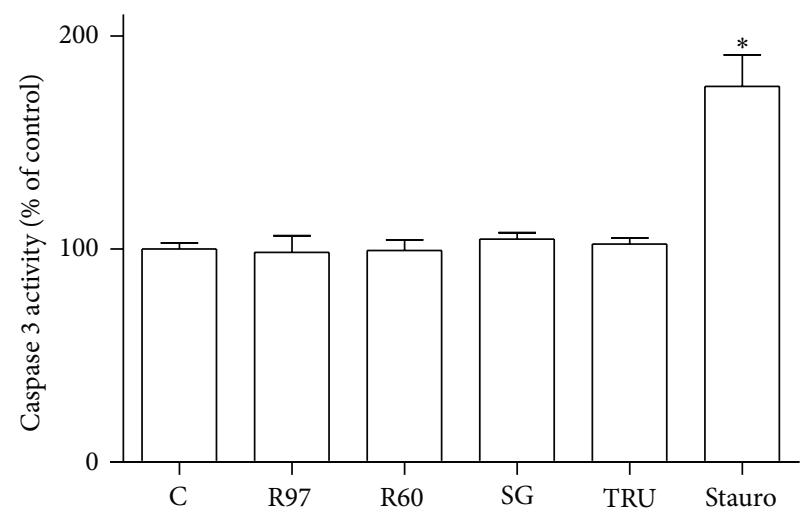

(b)

FIGURE 4: Caspase 3 activity in SH-SY5Y (a) and HL-60 (b) cells was evaluated in the presence of $1 \mathrm{mg} / \mathrm{mL}$ steviol glycosides incubated for 24 hours. Staurosporine (Stauro, $1 \mu \mathrm{g} / \mathrm{mL}$ for 4 hours) was used as positive control. Caspase 3 activity was measured spectrofluorimetrically after 24 hours in cell lysates as reported in Section 2. Each column represents the mean \pm SD of three independent experiments. Statistical analysis was performed by Bonferroni multiple comparison test following one-way ANOVA. ${ }^{*} P<0.05$, significantly different from control cells.

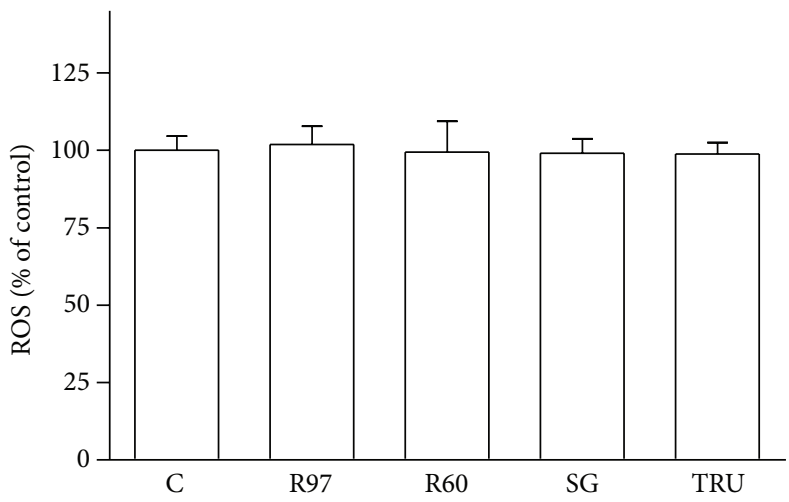

(a)

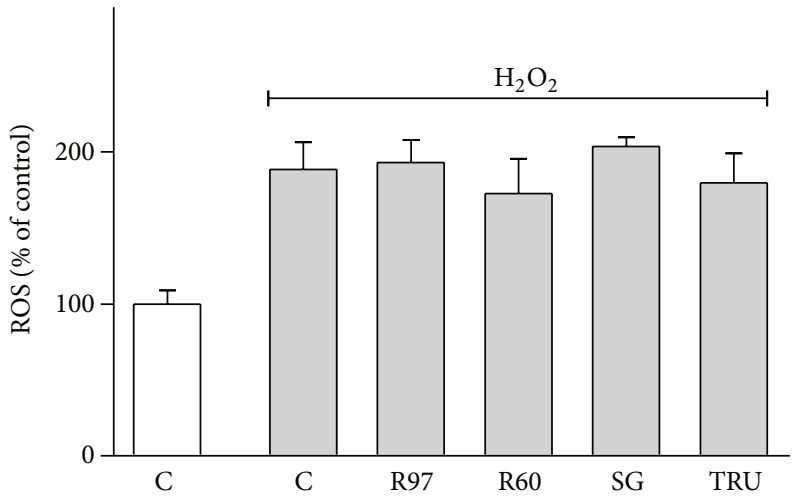

(c)

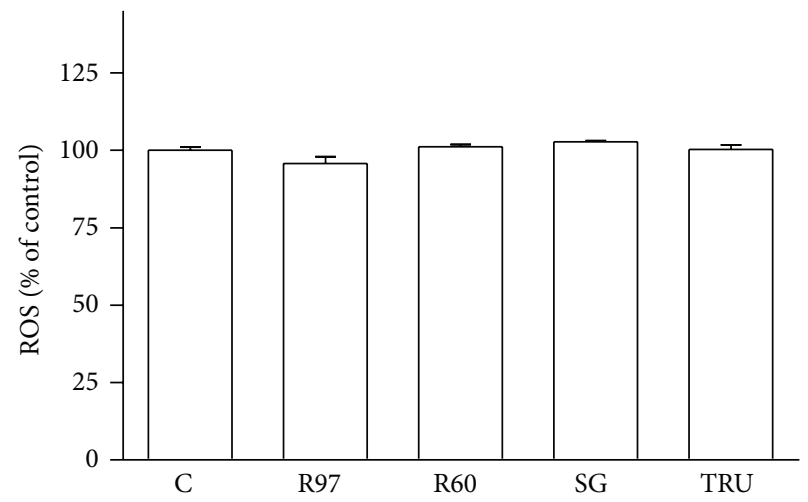

(b)

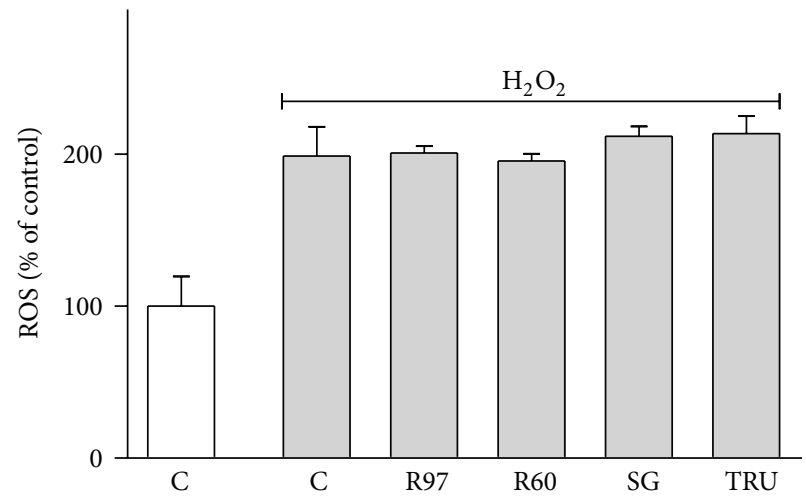

(d)

FIGURE 5: Effect of steviol glycosides on ROS levels in SH-SY5Y and HL-60 cells. SH-SY5Y (a) and HL-60 (b) cells were treated for 1 hour with different compounds $(5 \mathrm{mg} / \mathrm{mL})$; then basal ROS levels were measured by means of $\mathrm{H}_{2}$ DCFDA assay as described in Section 2 . Results are expressed as means \pm SD of four independent experiments $(n=8)$. Statistical analysis was performed by Bonferroni multiple comparison test following one-way ANOVA. Significant differences were not revealed. SH-SY5Y (c) and HL-60 (d) cells were preincubated for 1 hour with different compounds $(5 \mathrm{mg} / \mathrm{mL})$ and then exposed to oxidative stress generated by $100 \mu \mathrm{M} \mathrm{H}_{2} \mathrm{O}_{2}$ for 30 min. ROS levels were measured by means of $\mathrm{H}_{2}$ DCFDA assay as described in Section 2. Results are expressed as means \pm SD of four independent experiments $(n=8)$. Statistical analysis was performed by Bonferroni multiple comparison test following one-way ANOVA. Significant differences were not revealed among $\mathrm{H}_{2} \mathrm{O}_{2}$ treated cells. 


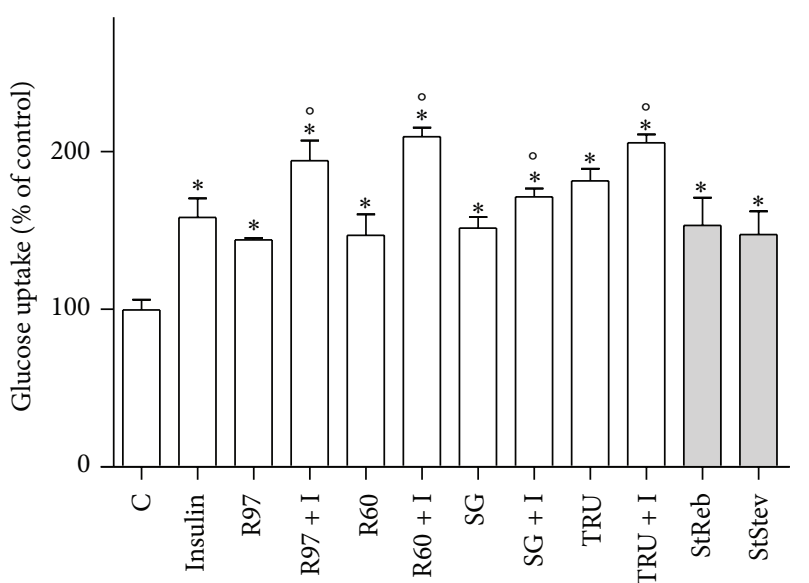

(a)

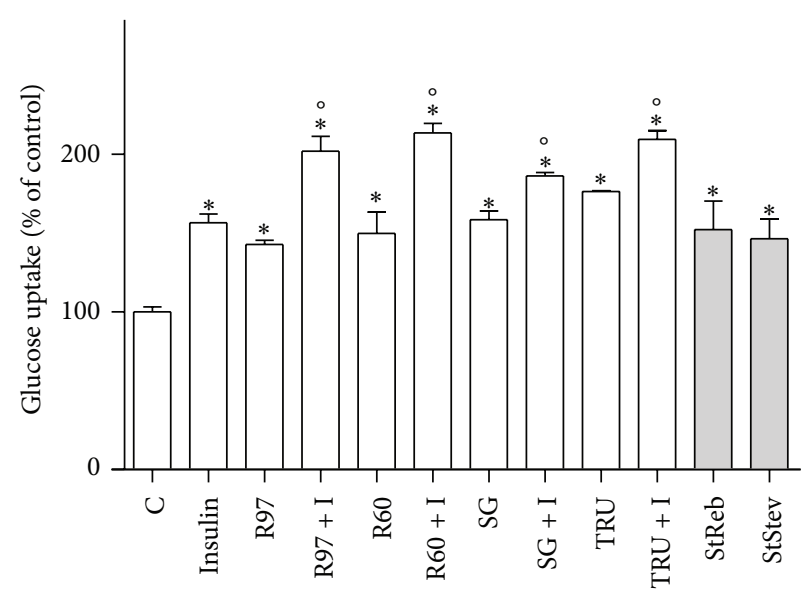

(b)

FiguRE 6: Effects of Stevia extracts on glucose transport activity compared to the effect of insulin. SH-SY5Y (a) and HL-60 (b) cells were treated with steviol glycosides $(1 \mathrm{mg} / \mathrm{mL})$, with $100 \mathrm{nM}$ insulin (I), with steviol glycosides and insulin simultaneously, or $1 \mathrm{mM}$ standard compounds (StReb, StStev). Glucose uptake was assayed as described in Section 2. Results are expressed as means \pm SD of three independent experiments, each performed in triplicate. Statistical analysis was performed by Bonferroni multiple comparison test following one-way ANOVA. ${ }^{*} P<0.05$, significantly different from control cells; ${ }^{\circ} \mathrm{P}<0.05$ significantly different from the corresponding cells not stimulated with insulin.

can hypothesize that this effect is due to rebaudioside A and stevioside, the two major components of Stevia extracts.

Furthermore, the influence of Stevia extracts on glucose transport activity was compared to the effect of $100 \mathrm{nM}$ insulin (Figure 6). Results reveal that Stevia extracts and insulin behave similarly, being Stevia extracts as efficient as insulin in increasing glucose uptake. The cotreatment with insulin and Stevia extracts causes a rise of glucose transport significantly higher than the increase due to insulin alone.

It is well known that insulin induces the translocation of GLUT4 from cytosolic storage vesicles to the plasma membrane, enhancing glucose transport. Recently, this phenomenon was observed also for neural cells in vitro, in particular the human neuroblastoma SH-SY5Y cells, through a phosphatidylinositol 3-kinase (PI3K)-dependent mechanism similar to the mechanism described in muscle or adipose tissues [28]. Translocation of GLUTs to the membrane has been reported as a consequence of various stimuli in many cellular types; in addition, changes in the expression of GLUTs have been described in response to several metabolic and oxidative stresses and in various physiological or pathological conditions. For example, insulin and ischemia induce GLUT1 movement to the membrane in rat heart [44]; doxorubicin recruits GLUT1 to the plasma membrane by a ROS-mediated mechanism in cardiomyocytes [37]; Lcysteine increases glucose uptake and GLUT3 levels in SHSY5Y cells [45]; growth factors, cytokines, hydrogen peroxide, and cholesterol depletion are able to increase glucose uptake and GLUT1 translocation in leukaemia cell lines [4649]. The expression of GLUT1 and GLUT4 in neuroblastoma and leukaemia cells following treatments with Stevia extracts or insulin was assessed by Western blot analysis on cell lysates. Figure 7 reports representative immunoblots for GLUT isoforms and the densitometric analysis in both cell lines. It can be seen that the increase in GLUT1 and GLUT4 content obtained following exposure to Stevia extracts is similar to that obtained by insulin stimulation. These results are in accordance with those observed in the evaluation of glucose transport activity.

To clarify the molecular mechanism by which Stevia extracts enhance glucose transport, the phosphorylation status of PI3K and Akt was evaluated following Stevia extract treatment and insulin stimulation. Insulin activates the PI3K/Akt pathway, critical for neuronal survival and growth, synaptic plasticity and development, and learning $[50,51]$. Indeed, stimulation of insulin receptor, localized in lipid rafts $[52,53]$, produces the phosphorylation of tyrosine receptor kinases and the activation of a signal transduction pathway involving PI3K and Akt. The interaction of insulin with its receptor is a regulator of growth and differentiation of leukaemia cells $[54,55]$. Highly specific insulin receptors have been identified on human promyelocytic leukaemia cells HL60 [56]. Immunoblotting results (Figure 8) show an increase of phosphorylated forms of both PI3K and Akt following the treatment with insulin or Stevia extracts, indicating a possible similar mechanism of action or, at least, a common signalling pathway.

To better characterize the mechanisms of glucose uptake induction by steviol glycosides, we used methylglyoxal (MG) as an inhibitor of the insulin receptor/PI3K/Akt pathway. MG is a reactive ketoaldehyde, product of many metabolic pathways, primarily glycolysis, which is considered the most relevant and reactive glycation agent in vivo. Advanced glycation end products (AGEs) have been implicated in development and progression of several diseases, including diabetes and its associated vascular complications, renal failure, cirrhosis, aging, and recently also in diabetic neuropathy and in Alzheimer's disease [57]. Furthermore, recent studies suggest a correlation between MG and insulin resistance [58]. 
SH-SY5Y cells

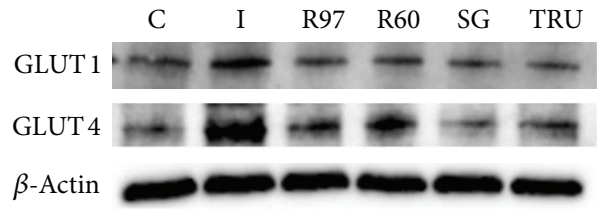

(a)

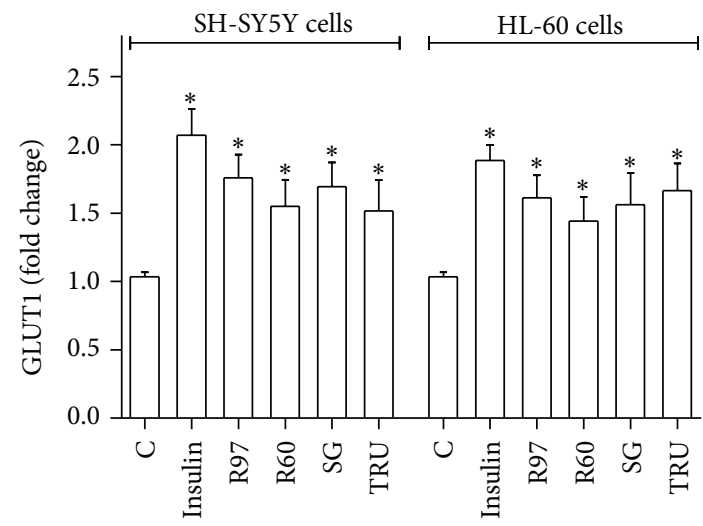

(c)

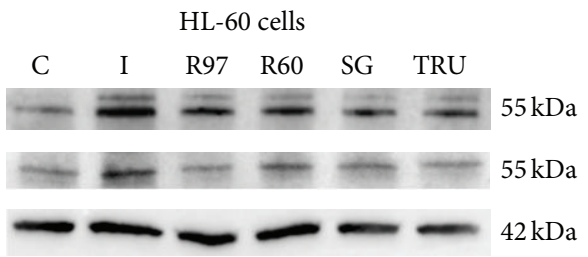

(b)

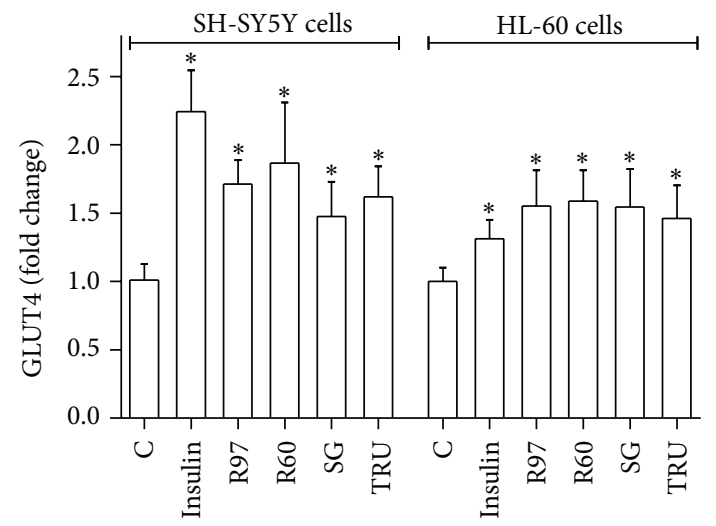

(d)

Figure 7: Effects of Stevia extracts on GLUT content. SH-SY5Y and HL-60 cells, treated with insulin or with steviol glycosides, were lysed with CelLytic M as described in Section 2. Cell lysates were electrophoresed and immunoblotted with the indicated antibodies, as described in Section 2. $\beta$-Actin detection was used as a control. Immunoblots representative of three independent experiments are reported for SH-SY5Y (a) and HL-60 (b) cell lines; densitometric analysis (normalized for $\beta$-actin content and expressed as fold of control) is shown for GLUT1 (c) and GLUT4 (d). ${ }^{*} P<0.05$, significantly different from control cells.

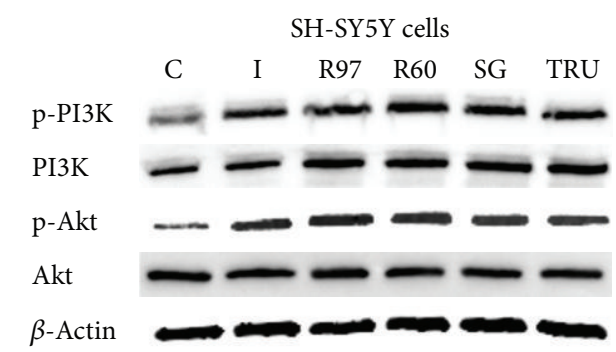

(a)

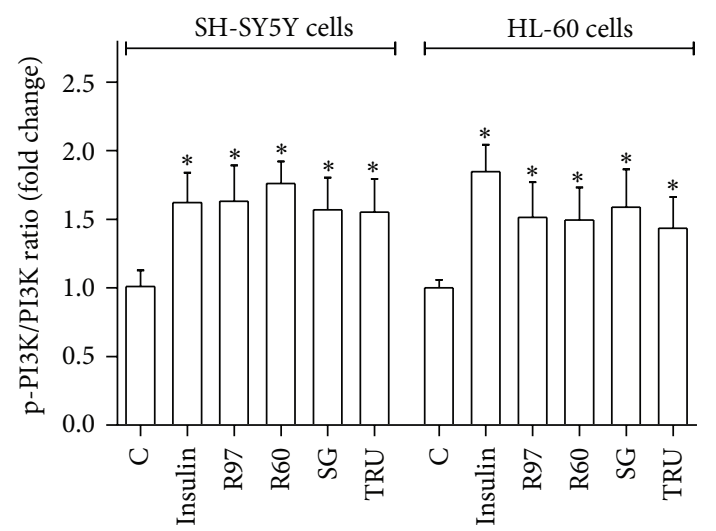

(c)

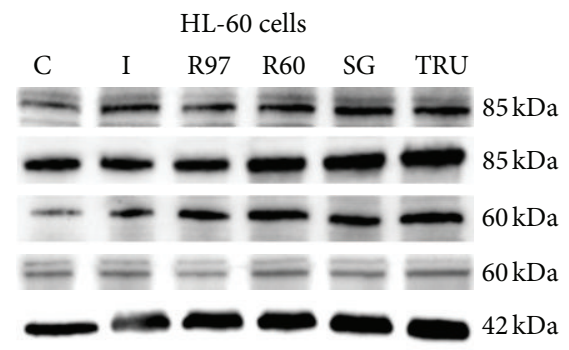

(b)

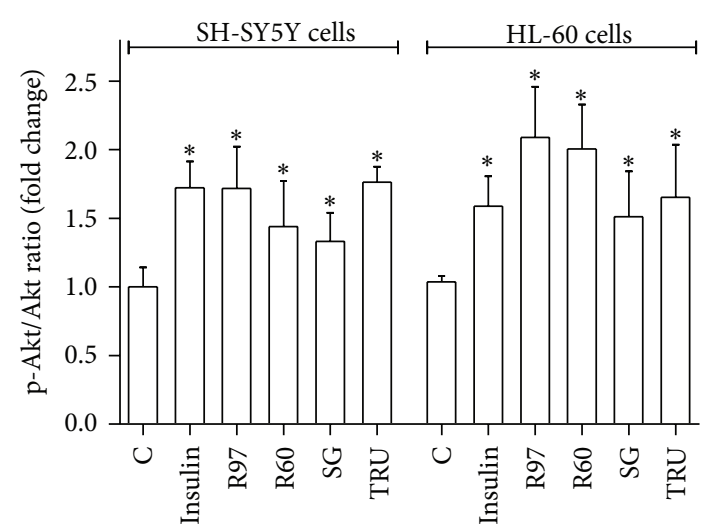

(d)

FIGURE 8: Effects of Stevia extracts on PI3K/Akt pathway. SH-SY5Y and HL-60 cells, treated with insulin or with steviol glycosides, were lysed with CelLytic $M$ as described in Section 2. Cell lysates were electrophoresed and immunoblotted with the indicated antibodies, as described in Section 2. $\beta$-Actin detection was used as a control. Immunoblots representative of three independent experiments are reported for SH-SY5Y (a) and HL-60 (b) cell lines; densitometric analysis of PI3K phosphorylation status is expressed as phospho-PI3K/total PI3K ratio (c) and densitometric analysis of Akt phosphorylation status is expressed as phospho-Akt/total Akt ratio (d). ${ }^{*} P<0.05$, significantly different from control cells. 


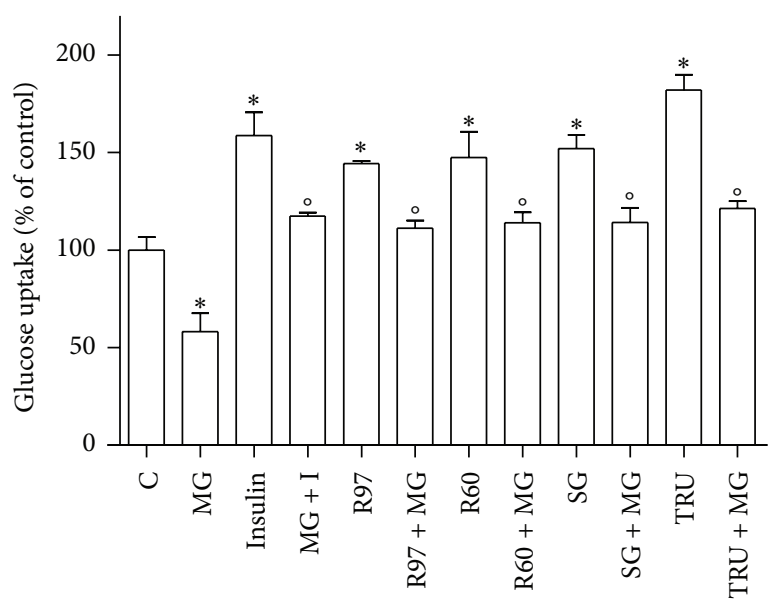

(a)

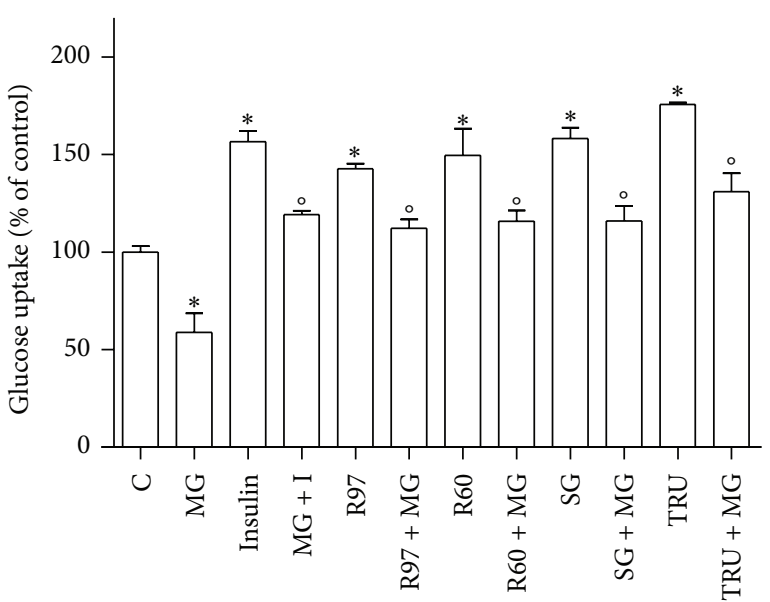

(b)

FIGURE 9: Effects of Stevia extracts on glucose transport activity compared to the effect of $0.1 \mathrm{mM}$ of methylglyoxal. SH-SY5Y (a) and HL60 (b) cells were treated with steviol glycosides, with insulin (I), with methylglyoxal (MG, 2 hours), and with steviol glycosides or insulin in the presence of MG. Glucose uptake was assayed as described in Section 2. Results are expressed as means \pm SD of three independent experiments, each performed in triplicate. Statistical analysis was performed by Bonferroni multiple comparison test following one-way ANOVA. ${ }^{*} P<0.05$, significantly different from control cells; ${ }^{\circ} \mathrm{P}<0.05$, significantly different from cells treated with $\mathrm{MG}$ alone.

Figure 9 shows that MG incubation (2 hours) induces a significant decrease in glucose transport and that the subsequent treatment with Stevia extracts or insulin is able to raise the glucose uptake, corroborating the hypothesis that Stevia extracts could act via PI3K/Akt pathway similar to insulin. As MG is a reactive aldehyde toxic to cells, MTT assay was performed to verify that the MG concentration $(0.1 \mathrm{mM})$ used to inhibit glucose transport did not influence cell viability (data not shown).

\section{Conclusions}

In this study, we evaluated the effects of steviol glycosides, extracted from Stevia rebaudiana Bertoni leaves, on glucose transport activity in two different cell lines. We demonstrated, for the first time to our knowledge, that rebaudioside A and stevioside, the major glycosides in Stevia extracts, are able to enhance glucose uptake in both $\mathrm{SH}$ SY5Y neuroblastoma and HL-60 myeloid leukaemia human cells, the raise being similar to that induced by insulin. Our data suggest that steviol glycosides act by modulating GLUT translocation through the PI3K/Akt pathway. Although further experiments are needed, these results support the hypothesis that steviol glycosides and insulin could share a similar mechanism in regulating glucose entry into cells. In conclusion, Stevia extracts, commercialised as zerocalorie natural sweeteners, are involved in insulin regulated glucose metabolism. These findings suggest that the use of Stevia extracts goes beyond their sweetening power and may also offer therapeutic benefits, supporting the use of botanicals dietary supplements to improve the quality of life.

\section{Authors' Contribution}

Benedetta Rizzo and Laura Zambonin contributed equally to this paper.

\section{Acknowledgments}

Authors are grateful to Eridania Sadam SpA that kindly provided Stevia rebaudiana Bertoni extracts. This work was supported by grants from Italian Ministry for Education, University and Research (MIUR), from the Italian Ministry of Economic Development (Project "Made in Italy-over 50"), and from Fondazione del Monte di Bologna e Ravenna, Italy. The funders had no role in study design, data collection and analysis, decision to publish, or paper preparation. The authors declare that there is no conflict of interests regarding the publication of this paper.

\section{References}

[1] J. R. Hanson and B. H. De Oliveira, "Stevioside and related sweet diterpenoid glycosides," Natural Product Reports, vol. 10, no. 3, pp. 301-309, 1993.

[2] A. D. Kinghorn and D. D. Soejarto, "Discovery of terpenoid and phenolic sweeteners from plants," Pure and Applied Chemistry, vol. 74, no. 7, pp. 1169-1179, 2002.

[3] P. Z. Zimmet, D. J. McCarty, and M. P. De Courten, “The global epidemiology of non-insulin-dependent diabetes mellitus and the metabolic syndrome," Journal of Diabetes and its Complications, vol. 11, no. 2, pp. 60-68, 1997.

[4] R. A. DeFronzo, "The triumvirate: $\beta$-cell, muscle, liver. A collusion responsible for NIDDM," Diabetes, vol. 37, no. 6, pp. 667-687, 1988. 
[5] "American Diabetes Association: Standards of Medical Care in Diabetes-2013," Diabetes Care, vol. 36, supplement 1, pp. S11S66, 2013.

[6] B. Crammer and R. Ikan, "Sweet glycosides from the Stevia plant," Chemistry in Britain, vol. 22, no. 10, pp. 915-917, 1986.

[7] V. Chatsudthipong and C. Muanprasat, "Stevioside and related compounds: therapeutic benefits beyond sweetness," Pharmacology and Therapeutics, vol. 121, no. 1, pp. 41-54, 2009.

[8] EFSA Panel on Food Additives and Nutrient Sources (ANS), "Scientific Opinion on safety of steviol glycosides for the proposeduses as a food additive," EFSA Journal, vol. 8, no. 4, p. 1537, 2010.

[9] European Food Safety Authority, "Revised exposure assessment for steviol glycosides for the proposed uses as a food additive," EFSA Journal, vol. 9, no. 1, p. 1972, 2011.

[10] JECFA (Joint FAO/WHO Expert Committee on Food Additives), Compendium of Food Additive Specifications, Monograph 5. Steviol glycosides, 2008, http://www.fao.org/ag/agn/jecfaadditives/details.html?id=898.

[11] JECFA (Joint FAO/WHO Expert Committee on Food Additives), "Safety evaluation of certain food additives. Prepared by the 69th meeting of the Joint FAO/WHO Expert Committee on Food Additives," WHO Food Additives Series, vol. 66, pp. 183220, 2009.

[12] S. K. Goyal, S. Samsher, and R. K. Goyal, "Stevia (Stevia rebaudiana) a bio-sweetener: a review," International Journal of Food Sciences and Nutrition, vol. 61, no. 1, pp. 1-10, 2010.

[13] G. Brahmachari, L. C. Mandal, R. Roy, S. Mondal, and A. K. Brahmachari, "Stevioside and related compounds-molecules of pharmaceutical promise: a critical overview," Archiv der Pharmazie, vol. 344, no. 1, pp. 5-19, 2011.

[14] M. Suttajit, U. Vinitketkaumnuen, U. Meevatee, and D. Buddhasukh, "Mutagenicity and human chromosomal effect of stevioside, a sweetener from Stevia rebaudiana Bertoni," Environmental Health Perspectives, vol. 101, no. 3, pp. 53-56, 1993.

[15] S. Tavarini and L. G. Angelini, "Stevia rebaudiana Bertoni as a source of bioactive compounds: the effect of harvest time, experimental site and crop age on steviol glycoside content and antioxidant properties," Journal of the Science of Food and Agriculture, vol. 93, no. 9, pp. 2121-2212, 2013.

[16] N. Shivanna, M. Naika, F. Khanum, and V. K. Kaul, "Antioxidant, anti-diabetic and renal protective properties of Stevia rebaudiana," Journal of Diabetes and Its Complications, vol. 27, no. 2, pp. 103-113, 2013.

[17] P. B. Jeppesen, S. Gregersen, C. R. Poulsen, and K. Hermansen, "Stevioside acts directly on pancreatic $\beta$ cells to secrete insulin: actions independent of cyclic adenosine monophosphate and adenosine triphosphate-sensitive $\mathrm{K}^{+}$-channel activity," Metabolism, vol. 49, no. 2, pp. 208-214, 2000.

[18] N. Lailerd, V. Saengsirisuwan, J. A. Sloniger, C. Toskulkao, and E. J. Henriksen, "Effects of stevioside on glucose transport activity in insulin-sensitive and insulin-resistant rat skeletal muscle," Metabolism, vol. 53, no. 1, pp. 101-107, 2004.

[19] P. Chan, K.-L. Wong, I.-M. Liu, T.-F. Tzeng, T.-L. Yang, and J.T. Cheng, "Antihyperglycemic action of angiotensin II receptor antagonist, valsartan, in streptozotocin-induced diabetic rats," Journal of Hypertension, vol. 21, no. 4, pp. 761-769, 2003.

[20] T.-H. Chen, S.-C. Chen, P. Chan, Y.-L. Chu, H.-Y. Yang, and J.-T. Cheng, "Mechanism of the hypoglycemic effect of stevioside, a glycoside of Stevia rebaudiana," Planta Medica, vol. 71, no. 2, pp. 108-113, 2005.
[21] P. B. Jeppesen, S. Gregersen, K. K. Alstrup, and K. Hermansen, "Stevioside induces antihyperglycaemic, insulinotropic and glucagonostatic effects in vivo: studies in the diabetic GotoKakizaki (GK) rats," Phytomedicine, vol. 9, no. 1, pp. 9-14, 2002.

[22] R. Abudula, V. V. Matchkov, P. B. Jeppesen, H. Nilsson, C. Aalkjær, and K. Hermansen, "Rebaudioside A directly stimulates insulin secretion from pancreatic beta cells: a glucosedependent action via inhibition of ATP-sensitive $\mathrm{K}^{+}$-channels," Diabetes, Obesity and Metabolism, vol. 10, no. 11, pp. 1074-1085, 2008.

[23] R. A. Medina and G. I. Owen, "Glucose transporters: expression, regulation and cancer," Biological Research, vol. 35, no. 1, pp. 9-26, 2002.

[24] R. Augustin, "The protein family of glucose transport facilitators: it's not only about glucose after all," IUBMB Life, vol. 62, no. 5, pp. 315-333, 2010.

[25] C. Leloup, M. Arluison, N. Kassis et al., "Discrete brain areas express the insulin-responsive glucose transporter GLUT4," Molecular Brain Research, vol. 38, no. 1, pp. 45-53, 1996.

[26] C. Choeiri, W. Staines, and C. Messier, "Immunohistochemical localization and quantification of glucose transporters in the mouse brain," Neuroscience, vol. 111, no. 1, pp. 19-34, 2002.

[27] V. C. Russo, K. Kobayashi, S. Najdovska, N. L. Baker, and G. A. Werther, "Neuronal protection from glucose deprivation via modulation of glucose transport and inhibition of apoptosis: a role for the insulin-like growth factor system," Brain Research, vol. 1009, no. 1-2, pp. 40-53, 2004.

[28] Y. Benomar, N. Naour, A. Aubourg et al., "Insulin and leptin induce Glut4 plasma membrane translocation and glucose uptake in a human neuronal cell line by a phosphatidylinositol 3-kinase-dependent mechanism," Endocrinology, vol. 147, no. 5, pp. 2550-2556, 2006.

[29] T. Maraldi, D. Fiorentini, C. Prata, L. Landi, and G. Hakim, "Stem cell factor and $\mathrm{H}_{2} \mathrm{O}_{2}$ induce GLUT1 translocation in M07e cells," BioFactors, vol. 20, no. 2, pp. 97-108, 2004.

[30] T. Maraldi, D. Fiorentini, C. Prata, L. Landi, and G. Hakim, "Glucose-transport regulation in leukemic cells: how can $\mathrm{H}_{2} \mathrm{O}_{2}$ mimic stem cell factor effects?" Antioxidants and Redox Signaling, vol. 9, no. 2, pp. 271-279, 2007.

[31] F. Ismail-Beigi, "Metabolic regulation of glucose transport," Journal of Membrane Biology, vol. 135, no. 1, pp. 1-10, 1993.

[32] A. R. Saltiel and C. R. Kahn, "Insulin signalling and the regulation of glucose and lipid metabolism," Nature, vol. 414, no. 6865, pp. 799-806, 2001.

[33] A. E. W. Hendrickson, P. Haluska, P. A. Schneider et al., "Expression of insulin receptor isoform A and insulin-like growth factor-1 receptor in human acute myelogenous leukaemia: effect of the dual-receptor inhibitor BMS-536924 in vitro," Cancer Research, vol. 69, no. 19, pp. 7635-7643, 2009.

[34] A. Tarozzi, F. Morroni, A. Merlicco et al., "Sulforaphane as an inducer of glutathione prevents oxidative stress-induced cell death in a dopaminergic-like neuroblastoma cell line," Journal of Neurochemistry, vol. 111, no. 5, pp. 1161-1171, 2009.

[35] A. Minarini, A. Milelli, V. Tumiatti et al., "Cystamine-tacrine dimer: a new multi-target-directed ligand as potential therapeutic agent for Alzheimer's disease treatment," Neuropharmacology, vol. 62, no. 2, pp. 997-1003, 2012.

[36] C. Angeloni, E. Motori, D. Fabbri et al., " $\mathrm{H}_{2} \mathrm{O}_{2}$ preconditioning modulates phase II enzymes through p38 MAPK and PI3K/Akt activation," American Journal of Physiology, vol. 300, no. 6, pp. H2196-H2205, 2011. 
[37] S. Hrelia, D. Fiorentini, T. Maraldi et al., "Doxorubicin induces early lipid peroxidation associated with changes in glucose transport in cultured cardiomyocytes," Biochimica et Biophysica Acta, vol. 1567, pp. 150-156, 2002.

[38] D. Fiorentini, C. Prata, T. Maraldi et al., "Contribution of reactive oxygen species to the regulation of Glutl in two hemopoietic cell lines differing in cytokine sensitivity," Free Radical Biology and Medicine, vol. 37, no. 9, pp. 1402-1411, 2004.

[39] D. D. Clarke and L. Sokoloff, "Circulation and energy metabolism of the brain," in Basic Neurochemistry, G. J. Siegel, B. W. Agranoff, R. W. Albers, S. K. Molinoff, P. B. Fisher, and M. D. Uhler, Eds., pp. 637-669, Lippincott-Ratven, Philadelphia, Pa, USA, 1999.

[40] F. Pasquier, A. Boulogne, D. Leys, and P. Fontaine, "Diabetes mellitus and dementia," Diabetes and Metabolism, vol. 32, no. 5, pp. 403-414, 2006.

[41] K. F. Neumann, L. Rojo, L. P. Navarrete, G. Farías, P. Reyes, and R. B. Maccioni, "Insulin resistance and Alzheimer's disease: molecular links amp; clinical implications," Current Alzheimer Research, vol. 5, no. 5, pp. 438-447, 2008.

[42] E. Adeghate, T. Donath, and A. Adem, "Alzheimer disease and diabetes mellitus: do they have anything in common?" Current Alzheimer Research, vol. 10, no. 6, pp. 609-617, 2013.

[43] E. Eruslanov and S. Kusmartsev, "Identification of ROS using oxidized DCFDA and flow-cytometry," Methods in Molecular Biology, vol. 594, pp. 57-72, 2010.

[44] S. Egert, N. Nguyen, and M. Schwaiger, "Myocardial glucose transporter GLUT1: translocation induced by insulin and ischemia," Journal of Molecular and Cellular Cardiology, vol. 31, no. 7, pp. 1337-1344, 1999.

[45] V. Gazit, R. Ben-Abraham, O. Vofsi, and Y. Katz, "L-cysteine increases glucose uptake in mouse soleus muscle and SH-SY5Y cells," Metabolic Brain Disease, vol. 18, no. 3, pp. 221-231, 2003.

[46] T. Maraldi, C. Prata, D. Fiorentini, L. Zambonin, L. Landi, and G. Hakim, "Signal processes and ROS production in glucose transport regulation by thrombopoietin and granulocyte macrophage-colony stimulation factor in a human leukaemic cell line," Free Radical Research, vol. 41, no. 12, pp. 1348-1357, 2007.

[47] C. Prata, T. Maraldi, L. Zambonin, D. Fiorentini, G. Hakim, and L. Landi, "ROS production and Glutl activity in two human megakaryocytic cell lines," BioFactors, vol. 20, no. 4, pp. 223233, 2004.

[48] C. Prata, T. Maraldi, D. Fiorentini, L. Zambonin, G. Hakim, and L. Landi, "Nox-generated ROS modulate glucose uptake in a leukaemic cell line," Free Radical Research, vol. 42, no. 5, pp. 405-414, 2008.

[49] C. Caliceti, L. Zambonin, C. Prata et al., "Effect of plasma membrane cholesterol depletion on glucose transport regulation in leukaemia cells," PLoS ONE, vol. 7, no. 7, Article ID e41246, 2012.

[50] L. P. van der Heide, G. M. J. Ramakers, and M. P. Smidt, "Insulin signaling in the central nervous system: learning to survive," Progress in Neurobiology, vol. 79, no. 4, pp. 205-221, 2006.

[51] R. R. Girgis, J. A. Javitch, and J. A. Lieberman, "Antipsychotic drug mechanisms: links between therapeutic effects, metabolic side effects and the insulin signaling pathway," Molecular Psychiatry, vol. 13, no. 10, pp. 918-929, 2008.

[52] C. Wu, S. Butz, Y.-S. Ying, and R. G. W. Anderson, "Tyrosine kinase receptors concentrated in caveolae-like domains from neuronal plasma membrane," Journal of Biological Chemistry, vol. 272, no. 6, pp. 3554-3559, 1997.
[53] J. Sánchez-Wandelmer, A. Dávalos, G. de la Peña et al., "Haloperidol disrupts lipid rafts and impairs insulin signaling in SH-SY5Y cells," Neuroscience, vol. 167, no. 1, pp. 143-153, 2010.

[54] T. J. Chaplinski, T. E. Bennett, and J. F. Caro, "Alteration in insulin receptor expression accompanying differentiation of HL-60 leukaemia cells," Cancer Research, vol. 46, no. 3, pp. 1203-1207, 1986.

[55] J. M. Lord, C. M. Bunce, R. J. Duncan et al., "Changes in insulin receptor expression in HL60 cells induced to differentiate towards neutrophils or monocytes," Journal of Molecular Endocrinology, vol. 1, no. 3, pp. 197-201, 1988.

[56] J. P. Abita, C. Gauville, and F. Saal, "Characterization of insulin receptors in human promyelocytic leukaemia cell HL60," Biochemical and Biophysical Research Communications, vol. 106, no. 2, pp. 574-581, 1982.

[57] M. Sousa Silva, R. A. Gomes, A. E. Ferreira, A. Ponces Freire, and C. Cordeiro, "The glyoxalase pathway: the first hundred years... and beyond," Biochemical Journal, vol. 453, no. 1, pp. $1-15,2013$.

[58] P. Matafome, C. Sena, and R. Seiça, "Methylglyoxal, obesity, and diabetes," Endocrine, vol. 43, no. 3, pp. 472-484, 2013. 


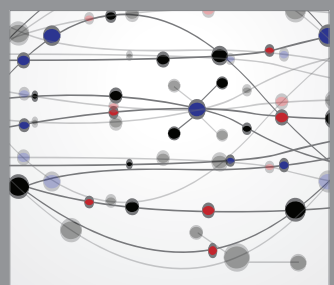

The Scientific World Journal
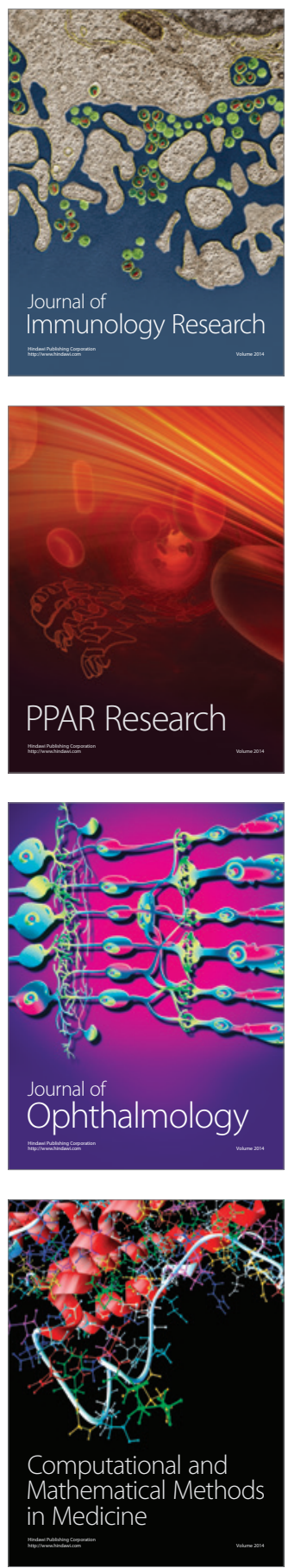

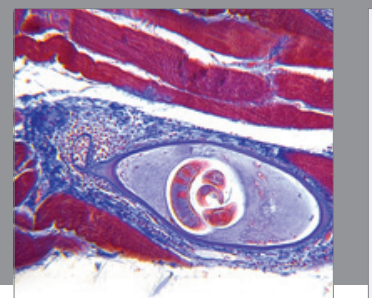

Gastroenterology

Research and Practice
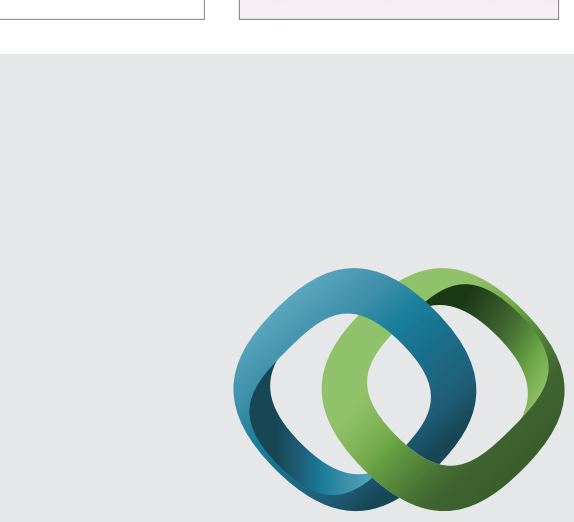

\section{Hindawi}

Submit your manuscripts at

http://www.hindawi.com
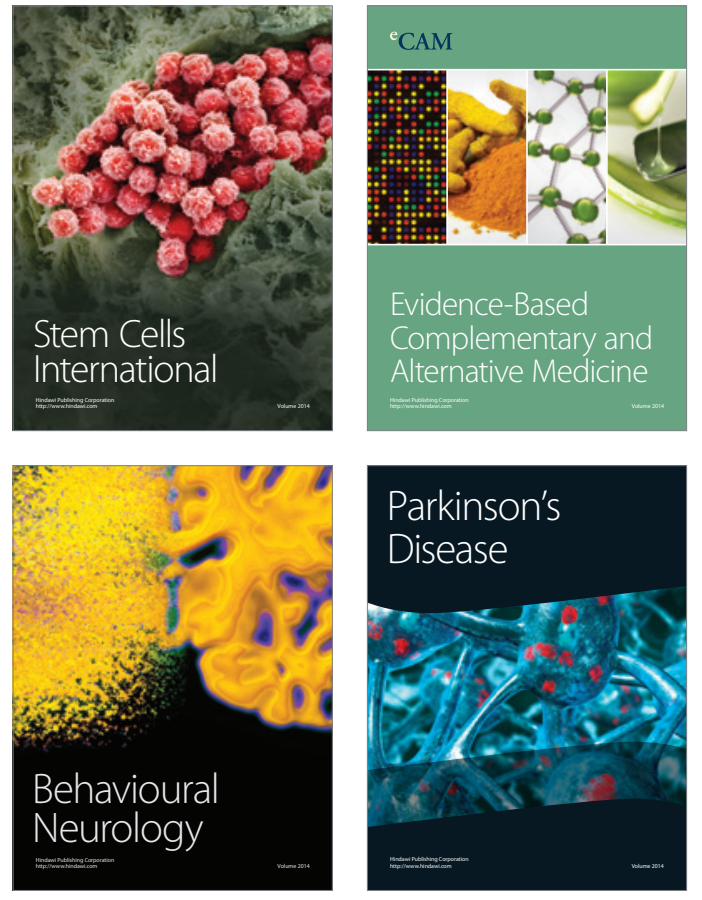
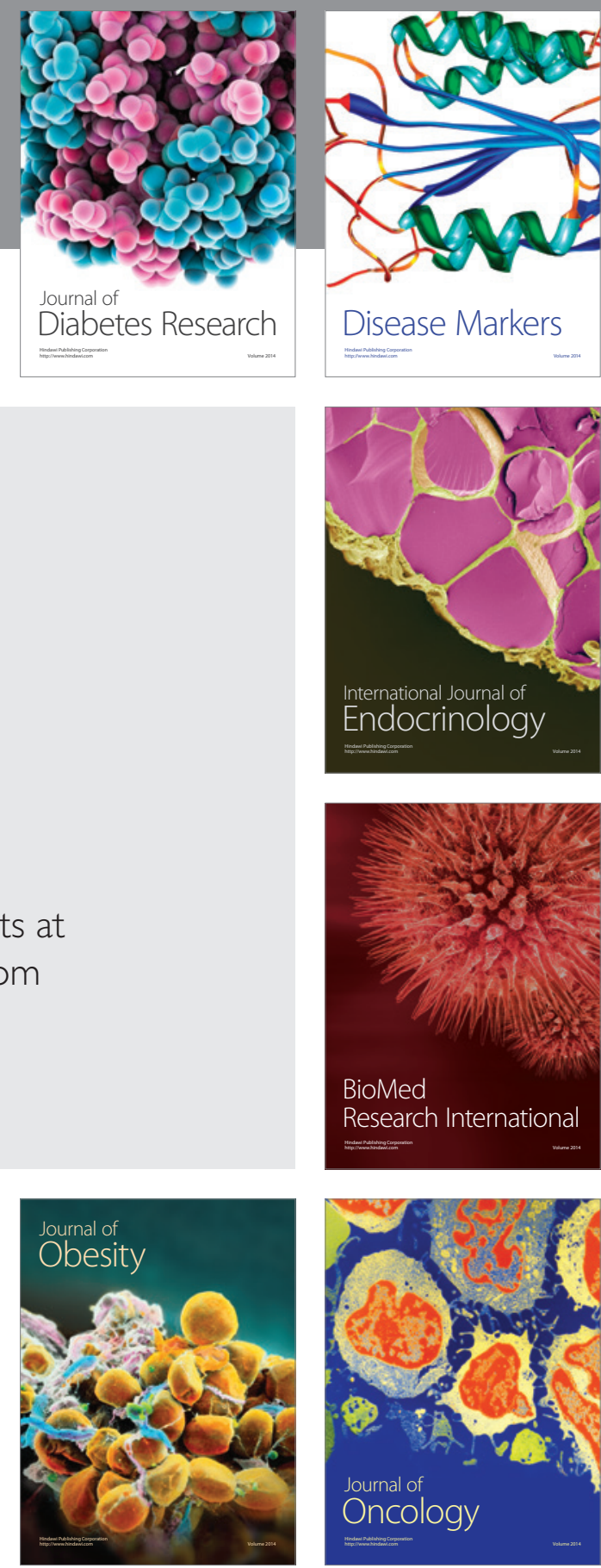

Disease Markers
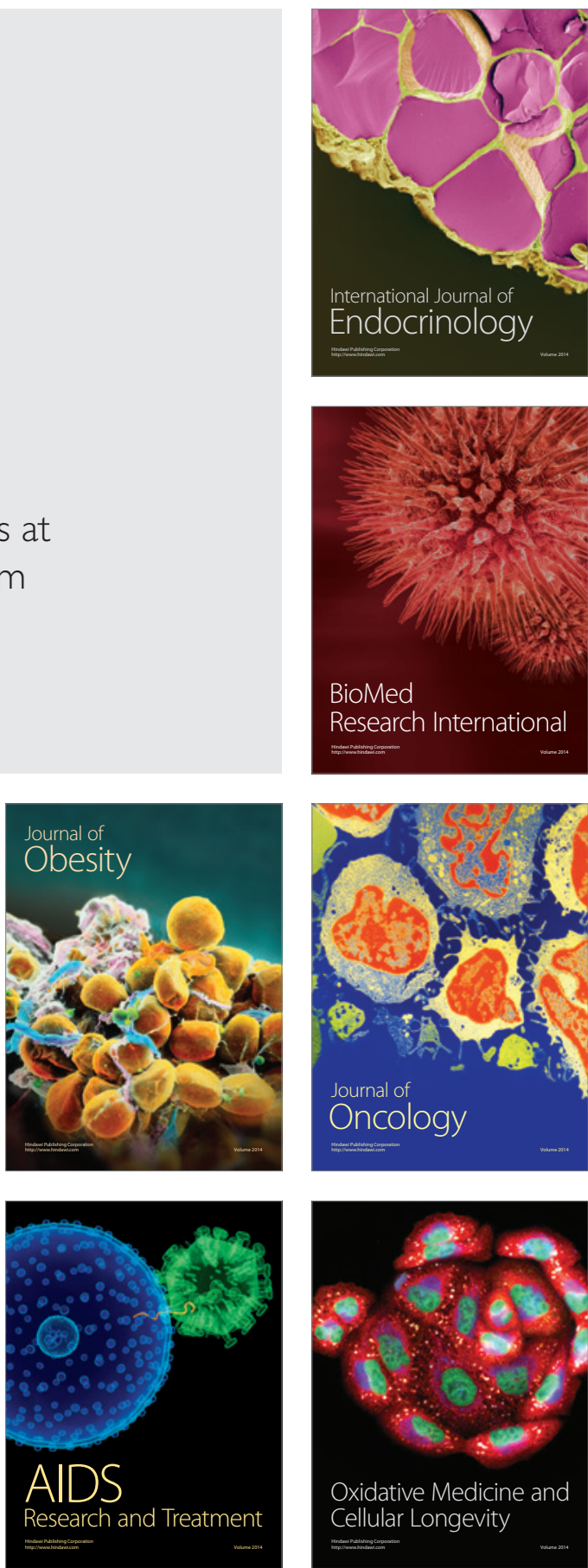